\title{
Peralihan Moda Transportasi Jasa Pengiriman Menggunakan Metode Analytical Hierarchy Process (AHP): Studi Kasus PT. XYZ
}

\author{
Yuliyani Nur Angraini ${ }^{* 1)}$, Meilani Rosita ${ }^{2)}$, dan Amalia Ananda Putri Taufiq ${ }^{3}$ \\ ${ }^{123)}$ Jurusan Teknik /Industri, Fakultas Teknik, Universitas Sebelas Maret \\ J1. Ir. Sutami 36A, Surakarta, 57126, Indonesia
}

\begin{abstract}
PT XYZ is the cargo company that had operate along Surabaya-Solo-Jakarta rute. This company opeated the bussiness by a traditional carrier that only used truck as a transportation mode. The company decision to used this mode because of its had any strengthen like the easyness of locations access and the more delivery frequency. But in its operations also had any weakness like the problem of time, quality and cost. The frequent problem is about the losses because of the cost of delivery is more than its benefit. So that, its required to changed the transportation mode to solved this losses. The changed of transportation mode that can be applicated is the used of train. We used an Analytical Hierarchy Process (AHP) to make decision about the best alternative in this problem. From the equation we have a percentage of the used of train can solved this problem $53 \%$ more than the used truck.
\end{abstract}

Keywords: Analytical Hierarchy Process, Peralihan Moda Transportasi, Jasa Pengiriman, Truk, Kereta Api

\section{Pendahuluan}

Sebagai pusat pertumbuhan dan pergerakan ekonomi di bidang industri dan perdagangan di Indonesia pada umumnya, dan di Pulau Jawa pada khusunya, pergerakan angkutan barang sepanjang koridor Surabaya-Solo-Jakarta sangat padat termasuk pergerakan angkutan barang jenis general cargo atau paket, terutama yang melalui jalur darat. Untuk saat ini jalur darat koridor Surabaya-Solo-Jakarta dilayani oleh moda kereta api dan truk. Namun dari segi kuantitas pengiriman barang ekspedisi masih didominasi oleh angkutan truk. Pemilihan moda truk banyak dipilih oleh perusahaan jasa pengiriman ekspedisi dikarenakan beberapa kelebihannya salah satunya adalah tidak terikat oleh waktu dimana pengiriman dapat dilakukan kapan saja apabila kuota pengiriman telah tercapai. PT. XYZ ini menggunakan jasa truk dalam pengiriman barang untuk koridor Surabaya-Solo-Jakarta sehingga banyak kendala yang masih menjadi kekurangan. Seperti waktu, biaya, dan kapasitas. Sedangkan jika dalam pengiriman barang menggunakan moda kereta api memiliki beberapa kelebihan dibandingkan moda truk, beberapa kelebihan moda kereta api kapasitas angkut akan lebih besar, waktu perjalanan yang relatif cepat, bebas pungutan liar dan keamanan serta keselamatan barang lebih terjamin. Untuk pengiriman general cargo rute Surabaya-Solo-Jakarta PP, PT.KAI menyediakan KA Parcel dan KA ONS (Over Night Service). Namun kereta api terkendala oleh masalah frekuensi keberangkatan yang sangat terbatas. Beberapa faktor tersebut dapat menjadi suatu permodelan yang dapat dilakukan untuk mengetahui perilaku penyedia jasa pengiriman paket koridor Surabaya-Solo-Jakarta dalam memilih moda antara kereta api dan truk. Dari model ini dapat diketahui faktor apa saja yang menjadi pertimbangan oleh penyedia jasa angkutan barang dalam

\footnotetext{
*Correspondance : yulianiangraini@gmail.com
} 
memilih moda. Hasil pemodelan ini nantinya dapat menjadi bahan pertimbangan arah kebijakan transportasi angkutan barang koridor Surabaya-Solo-Jakarta untuk PT. XYZ.

\section{Studi Literature}

\section{Pemilihan Moda Tranportasi}

Transportasi adalah suatu kegiatan pemindahan barang (muatan) dan penumpang dari satu tempat ke tempat yang lain. Pemilihan moda sangat sulit dimodelkan, walaupun hanya dua buah moda yang akan digunakan (umum atau pribadi). Hal ini disebabkan banyaknya faktor yang sulit dikuantifikasi, misalnya kenyamanan, keamanan, kemudahan, biaya, waktu tempuh atau ketersediaan angkutan pada saat diperlukan.

\section{Faktor yang Mempengaruhi Pemilihan Moda}

Faktor-faktor yang mempengaruhi seseorang dalam memilih suatu moda transportasi dapat dibedakan atas empat kategori sebagai berikut (Tamin, 2008):

1. Ciri pengguna jalan

2. Ciri pergerakan

3. Ciri fasilitas moda transportasi

4. Ciri kota atau zona

Proses Hirarki Analitik (Analitycal Hierarchy Process)

Analisis Hirarki (Analytic Heirarchy Prosess) adalah sebuah hirarki fungsional dengan input utamanya persepsi manusia. Dengan hirarki, suatu masalah kompleks dan tidak terstruktur dipecahkan kedalam kelompok-kelompoknya. Kemudian kelompok tersebut diatur menjadi suatu bentuk hirarki (Brojonegoro 1992). Tahapan proses pengambilan keputusan dengan menggunakan AHP secara garis besar adalah sebagai berikut :

1. Penstrukturan masalah kedalam hirarki

Penstrukturan ini bertujuan agar masalah yang kompleks menjadi lebih mudah diselesaikan, sebab telah terbagi-bagi menjadi beberapa submasalah yang lebih sederhana dan skalanya lebih kecil. angan subyektif, sebagai patokan untuk mengkuantifikasikan pertimbangan tersebut.

2. Mensintesakan hasil

Pendapat-pendapat yang telah diberikan angka numerik dengan skala seperti pada Tabel 1, menjadi masukan untuk diolah melalui suatu prosedur tertentu menjadi bobot antar faktor. Langkah pertama sebelum menentukan prioritas setiap elemen dalam pengambilan keputusan adalah dengan melakukan perbandingan berpasangan.

Tabel 1. Skala Penilaian AHP (Cabala, 2010)

\begin{tabular}{cc}
\hline Intensitas Kepentingan & Definisi Verbal \\
\hline 1 & Kedua sama penting \\
3 & Sedikit lebih penting \\
5 & Lebih penting \\
7 & Sangat penting \\
9 & Mutlak lebih penting \\
$2,4,6,8$ & Nilai tengah \\
\hline
\end{tabular}

3. Penyusunan prioritas

Apabila partisipasi telah memasukkan persepsinya untuk setiap perbandingan antara elemenelemen yang berada dalam satu level atau yang dapat diperbandingkan maka untuk mengetahui elemen mana yang paling penting disukai atau paling penting, disusun sebuah matriks perbandingan. Setelah matriks pairwais terbentuk maka langkah selanjutnya adalah mengukur bobot prioritas setiap elemen. Hasil akhir dari perhitungan bobot prioritas tersebut merupakan suatu bilangan desimal dibawah satu. 
4. Konsistensi logis

Semua elemen dikelompokkan secara logis dan diperingatkan secara konsisten sesuai dengan suatu kriteria yang logis. Matriks bobot yang diperoleh dari hasil perbandingan secara berpasangan tersebut harus mempunyai hubungan kardinal dan ordinal. Penghitungan konsistensi logis dilakukan dengan mengikuti langkah-langkah sebagai berikut

a. Hasil penjumlahan tiap baris pada matriks perbandingan dikali bobot prioritas baris tersebut dan hasilnya dibagi kembali dengan bobot prioritas kemudian di jumlahkan untuk semua baris.

b. Hasilnya dibagi dengan jumlah elemen $(n)$, akan didapat $\lambda$ maks.

c. Menghitung Indeks Konsistensi $(C I)$

$C I=\frac{\lambda \mathrm{maks}-\mathrm{n}}{\mathrm{n}-1}$

d. Menghitung Rasio Konsistensi $(C R)$

$C R=C I / R I$

di mana $R I$ adalah indeks random konsistensi. Jika rasio konsistensi $\leq 0,1$ maka hasil perhitungan dapat dibenarkan.

Tabel 2. Nilai Indeks Random Konsistensi (Sukarto, 2006)

\begin{tabular}{ccccccccccccccc}
\hline$N$ & 1,2 & 3 & 4 & 5 & 6 & 7 & 8 & 9 & 10 & 11 & 12 & 13 & 14 & 15 \\
\hline$R I$ & 0,00 & 0,58 & 0,90 & 1,12 & 1,24 & 1,32 & 1,41 & 1,45 & 1,49 & 1,51 & 1,48 & 1,56 & 1,57 & 1,59 \\
\hline
\end{tabular}

\section{Metode Penelitian}

\section{Observasi}

Penelitian dimulai dengan melakukan observasi langsung ke perusahaan terkait. Setelah itu, dibuatlah daftar masalah yang menjadi penghambat di perusahaan tersebut, salah satunya adalah biaya pengiriman yang lebih besar dari tarif pengiriman yang dibebankan ke pelanggan. Masalah kemudian disusun ke dalam hirarki untuk membantu dalam penentuan metode yang digunakan dalam menyelesaikan masalah tersebut.

\section{Pengumpulan Data}

Dengan menggunakan hirarki tersebut dapat disusun sebuah kuesioner untuk mendapatkan nilai matriks perbandingan. Kuesioner berjumlah 5 diberikan kepada 1 Kepala Cabang PT XYZ, 2 karyawan PT XYZ dan 2 karyawan PT Herona. Penggunaan kuesioner bagi PT Herona digunakan untuk mendapatkan informasi mengenai karakteristik alternatif kereta api. Kuesioner yang diperuntukkan kepada Kepala Cabang PT XYZ berisi perbandingan antara tujuan penyelesaian masalah dengan kriteria. Sedangkan kuesioner yang diperuntukkan kepada 2 karyawan PT XYZ dan 2 karyawan PT Herona berisi perbandingan alternatif terhadap kriteria yang digunakan untuk mencapai tujuan.

\section{Pengolahan Data}

Selanjutnya, dibuatlah matrik perbandingan berpasangan kriteria untuk permasalahan peralihan moda transportasi untuk mengakomodasi kondisi ketika biaya pengiriman lebih dari pembayaran (negative margin). Matrik tersebut dinormalisasi dan diuji konsistensinya. Matriks perbandingan berpasangan juga dibuat untuk alternatif moda transportasi dan dilakukan normalisasi. Dari dua matriks perbandingan berpasangan tersebut disusun matrik perbandingan alternatif berdasarkan kriteria. Akhirnya dapat diketahui bobot untuk masing-masing moda transportasi dan dapat diputuskan moda transportasi terbaik. 


\section{Hasil dan Pembahasan}

\section{Penyusunan Masalah Dalam Hirarki}

Permasalahan yang menjadi dasar diperlukannya pemilihan moda transportasi yakni peralihan moda transportasi untuk mengakomodasi kondisi ketika biaya pengiriman lebih dari pembayaran (negative margin). Kriteria yang dianggap mampu untuk menyelesaikan kedua permasalahan tersebut diantaranya:

1. Kecepatan

2. Biaya

3. Frekuensi pengiriman

4. Efisiensi rute pengiriman.

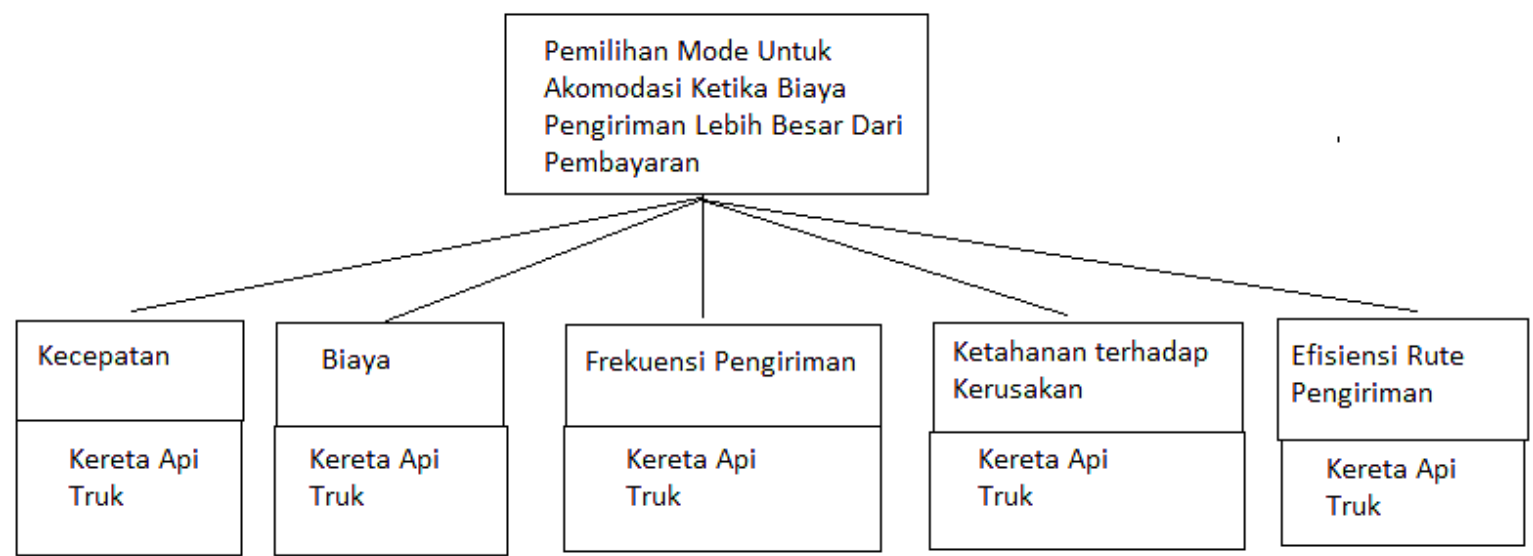

Gambar 1. Skema Hirarki Pemilihan Moda

\section{Membuat Matrik Perbandingan Berpasangan, Normalisasi Matrik dan Perhitungan Bobot Prioritas Untuk Kriteria}

Kriteria yang ada dalam hirarki disusun menjadi matrik menggunakan angka penilaian yang didapat dari kuesioner. Angka penilaian tersebut menunjukkan tingkat kepentingan kriteria satu relatif terhadap yang lain dalam kemampuannya menyelesaikan masalah yang ada.

Tabel 3. Matrik Perbandingan Berpasangan Penilaian Kriteria

\begin{tabular}{lccccc}
\hline Kriteria & Kecepatan & Biaya & $\begin{array}{c}\text { Frekuensi } \\
\text { Pengiriman }\end{array}$ & $\begin{array}{c}\text { Ketahanan } \\
\text { terhadap } \\
\text { Kerusakan }\end{array}$ & $\begin{array}{c}\text { Efisiensi } \\
\text { Rute } \\
\text { Pengiriman }\end{array}$ \\
\hline Kecepatan & 1 & 0,33 & 0,20 & 2 & 0,25 \\
\hline Biaya & 3 & 1 & 1 & 7 & 1 \\
\hline Frekuensi Pengiriman & 5 & 1 & 1 & 5 & 1 \\
\hline Ketahanan terhadap Kerusakan & 0,50 & 0,14 & 0,20 & 1 & 0,33 \\
\hline Efisiensi Rute Pengiriman & 4 & 1 & 1 & 3 & 1 \\
\hline
\end{tabular}

Perhitungan normalisasi dapat dilakukan dengan membagi tiap entri dengan jumlah kolom yang ada pada entri. Bobot prioritas didapatkan dari rata-rata hasil normalisasi untuk setiap baris.

Tabel 4. Normalisasi Matrik dan Bobot Prioritas Kriteria

\begin{tabular}{lcccccc}
\hline \multicolumn{1}{c}{ Kriteria } & Kecepatan & Biaya & $\begin{array}{c}\text { Frekuensi } \\
\text { Pengiriman }\end{array}$ & $\begin{array}{c}\text { Ketahanan } \\
\text { terhadap } \\
\text { Kerusakan }\end{array}$ & $\begin{array}{c}\text { Efisiensi } \\
\text { Rute } \\
\text { Pengiriman }\end{array}$ & $\begin{array}{c}\text { Bobot } \\
\text { Prioritas }\end{array}$ \\
\hline Kecepatan & 0,07 & 0,10 & 0,06 & 0,11 & 0,07 & 0,08 \\
\hline 0,08Biaya & 0,22 & 0,29 & 0,29 & 0,39 & 0,28 & 0,29 \\
\hline Frekuensi Pengiriman & 0,37 & 0,29 & 0,29 & 0,28 & 0,28 & 0,30 \\
\hline $\begin{array}{l}\text { 0,30Ketahanan terhadap } \\
\text { Kerusakan }\end{array}$ & 0,04 & 0,04 & 0,06 & 0,06 & 0,09 & 0,06 \\
\hline Efisiensi Rute Pengiriman & 0,30 & 0,29 & 0,29 & 0,17 & 0,28 & 0,26 \\
\hline
\end{tabular}




\section{Perhitungan Uji Konsistensi}

Dari perhitungan indeks konsistensi didapatkan nilai $C R$ sebesar 0,09 untuk matriks perbandingan penilaian kriteria. Karena matriks perbandingan penilaian bernilai kurang dari 0,1 maka matriks tersebut konsisten.

Membuat Matrik Perbandingan Berpasangan, Normalisasi Matrik dan Perhitungan Bobot Prioritas Untuk Alternaif Moda Transportasi

Alternatif moda transportasi yang ada dalam hirarki disusun menjadi matrik menggunakan angka penilaian yang didapat dari kuesioner. Angka penilaian tersebut menunjukkan tingkat kesesuaian alternatif satu relatif terhadap yang lain terhadap kriteria yang ada.

Tabel 5. Matrik Perbandingan Penilaian Mode Berdasarkan Kecepatan

\begin{tabular}{lcc}
\hline \multicolumn{1}{c}{ Moda } & Truk & Kereta Api \\
\hline Truk & 1 & $1 / 4$ \\
\hline Kereta Api & 4 & 1
\end{tabular}

Tabel 6. Matrik Perbandingan Penilaian Mode Berdasarkan Biaya

\begin{tabular}{lcc}
\hline \multicolumn{1}{c}{ Moda } & Truk & Kereta Api \\
\hline Truk & 1 & $1 / 3$ \\
\hline Kereta Api & 3 & 1 \\
\hline
\end{tabular}

Tabel 7. Matrik Perbandingan Penilaian Mode Berdasarkan Frekuensi Pengiriman

\begin{tabular}{lcc}
\hline \multicolumn{1}{c}{ Moda } & Truk & Kereta Api \\
\hline Truk & 1 & 4 \\
\hline Kereta Api & $1 / 4$ & 1 \\
\hline
\end{tabular}

Tabel 8. Matrik Perbandingan Penilaian Mode Berdasarkan Ketahanan terhadap Kerusakan

\begin{tabular}{lcc}
\hline \multicolumn{1}{c}{ Moda } & Truk & Kereta Api \\
\hline Truk & 1 & $1 / 7$ \\
\hline Kereta Api & 7 & 1
\end{tabular}

Tabel 9. Matrik Perbandingan Penilaian Mode Berdasarkan Efisiensi Rute Pengiriman

\begin{tabular}{lcc}
\hline \multicolumn{1}{c}{ Moda } & Truk & Kereta Api \\
\hline Truk & 1 & $1 / 2$ \\
\hline Kereta Api & 2 & 1 \\
\hline
\end{tabular}

Perhitungan normalisasi dilakukan pada setiap matriks perbandingan penilaian alternatif berdasarkan kriteria. Bobot prioritas masing-masing matriks didapat dari rata-rata setiap baris pada matriks normalisasi.

Tabel 10. Rekapitulasi Bobot Prioritas Alternatif Berdasarkan Kriteria

\begin{tabular}{lccccc}
\hline Alternatif & Kecepatan & Biaya & $\begin{array}{c}\text { Frekuensi } \\
\text { Pengiriman }\end{array}$ & $\begin{array}{c}\text { Ketahanan } \\
\text { terhadap } \\
\text { Kerusakan }\end{array}$ & $\begin{array}{c}\text { Efisiensi } \\
\text { Rute } \\
\text { Pengiriman }\end{array}$ \\
\hline Truk & 0,20 & 0,25 & 0,80 & 0,13 & 0,33 \\
\hline Kereta Api & 0,80 & 0,75 & 0,20 & 0,88 & 0,67 \\
\hline
\end{tabular}

Besarnya rangking pemilihan alternatif didapat dari perkalian antara rekapitulasi bobot prioritas alternatif dengan bobot prioritas kriteria permasalahan. Dari hasil perhitungan rangking pemilihan alternatif moda diketahui bahwa peralihan ke moda transportasi kereta api dapat membantu menyelesaikan permasalahan yang ada.

Tabel 12. Rangking Pemilihan Moda

\begin{tabular}{ccc}
\hline Peringkat & Alternatif & Bobot Prioritas \\
\hline 1 & Kereta Api & $57 \%$ \\
\hline 2 & Truk & $43 \%$ \\
\hline
\end{tabular}




\section{Kesimpulan}

Dari pengolahan data menggunakan matrik perbandingan alternatif berdasarkan kriteria dari beberapa moda transportasi, didapatkan bobot alternatif untuk masing-masing moda transportasi dalam kemampuannya mengatasi permasalahan untuk mengakomodasi ketika biaya pengiriman lebih besar daripada pendapatan yang dibayarkan, kereta api memiliki bobot lebih tinggi dibandingkan dengan moda transportasi awal di PT XYZ yang menggunakan truk. Sehingga dapat ditarik kesimpulan bahwa perusahaan dapat beralih ke moda transportasi kereta api dengan pertimbangan-pertimbangan yang telah dijelaskan sebelumnya. Untuk penelitian selanjutnya, dapat dipertimbangkan adanya backhaul yang berasal dari koridor tujuan pengiriman.

\section{Daftra Pustaka}

Brojonegoro, B. (1992). Teori dan Aplikasi Model AHP. Pusat Antar Univesitas, Studi Ekonomi, UI.Jakarta.

Cabala, P. (2010). Using The Analytical Hierarchy Process In Evaluating Decision Alternatives. Departemen Of Management Process Cracow University of Economics. Rakowicka.

Sukarto, H. (2006). Pemilihan Model Transportasi di DKI Jakarta Dengan Analisis Kebijakan Proses Hirarki Analitik. Jurnal Teknik Sipil. Vol 3.

Tamin, O. (2008). Perencanaan, Pemodelan, dan Rekayasa Transportasi: Teori, contoh soal, dan aplikasi, Penerbit ITB, Bandung. 